\title{
ULTRASTRUCTURE AND MORPHOLOGY OF THE RESORPTIVE MARGIN OF BOVINE OSTEOCLASTS
}

\author{
H. ČERNÝ \\ Department of Anatomy, Histology and Embryology, University \\ of Veterinary Science, 61242 Brno
}

Received fuly 15, 1981

\begin{abstract}
Černý H.: Ultrastructure and Morphology of the Resorptive Margin of Bovine Osteoclasts. Acta vet. Brno, 52, 1983: 3-13.

Ultrastucture of the resorptive margin of the osteoclast was studied from the osteoid zone of endochondral ossification of the growth cartilage in the metaphyseal rim of the tuber coxae using 4 bovine fetuses aged 246 to 271 days. The material was routinely processed for electron microscopy.

The multinucleated osteoclast forms a specialized and polar structure, a resorptive margin, at sites of its contact with the mineralized ground substance of the cartilage. This resorptive margin is analogous with the ruffled border of the osteoclasts. In the electron-microscopic field typical structures present in the resorptive margin include: shallow invaginations of the plasmalemma and the modified cytoplasm containing electron-dense strongly osmiophilic material and no other organelles. In cytoplasm of the resorptive margin only minute vesicles limited by a unit membrane are found which contain finely granular material of various densities.

The resorptive margin has been generally described as a concave structure. In our material, however, morphologically variable shapes of the resorptive margin were observed in the two-dimensional profiles, e.g. open-ring or circular, completely closed structures situated intracellularly. Morphology of the resorptive margin is determined to a certain degree by the phagocytic activity in this functionally very active area. Among the organelles present in the osteoclast, only those presumed to be involved in the intracellular transport of the resorbed substances into the extracellular space and into the blood capillaries were investigated.
\end{abstract}

Cattle, endochondral ossification, osteoclast, resorptive margin, cartilage resorption.

In the course of endochondral ossification of the growth cartilage the cartilaginous model is gradually replaced by newly formed bone tissue. Only a small portion of the ground substance of the cartilage model serves as a scaffolding for the forming bone tissue. The mineralized tissue is destroyed by activity of mononucleated (Horn and Dvoŕák 1977, 1980) and multinucleated cells (Hancox 1972; Holtrop et al. 1979; Kallio et al. 1972; Knese 1972; Lucht 1972; Mal$\mathrm{kani}$ et al. 1973). The cartilage model is thus resorbed by the direct action of clastic cellular elements present in the resorptive margin of the cell which in turn are in direct contact with the mineralized tissue.

Multinucleated cells are but one part of a complex mechanism of resorption of the mineralized cartilaginous ground substance. At the contact site they form a specialized structure, the so-called resorptive margin. It has been described in detail for guinea pig osteoclasts by Malkani et al. (1973). Structural details of this modified cytoplasm, this ,ruffled border“ have been reported in detail by $S$ chenket al. (1967) and S cott (1967). Formation of the ruffled border by cytoplasmic invaginations enlarges substantially the resorptive surface, plasmalemma (Scott and Pease 1956). The "ruffled border", including the specialized cytoplasm, is the centre of enhanced cellular activity and many substances are taken up from the extracellular space into cytoplasmic, phagocytic vesicles of the osteoclast (Kallio et al. 1972: Lucht 1972). 
The structure of the osteoclast and its cytoplasmic contact with the mineralized matrix, and its function in the mechanism of mineralized tissue resorption has been described by Knese (1972).

\section{Materials and Methods}

Material for this electron microscopic study was collected from the growth cartilage of the tuber coxae of four bovine fetuses aged 246 to 271 days. The samples from the osteoid zone of endochondral ossification were fixed in $4 \%$ glutaraldehyde in $0.1 \mathrm{M}$ phosphate buffer at $\mathrm{pH} 7.4$ for $4 \mathrm{~h}$. The samples were then decalcified in $0.1 \mathrm{M}$ EDTA with $4 \%$ glutaraldehyde at pH 7.4 for $14-16 \mathrm{~h}$. Rinsed samples were postfixed in $1 \% \mathrm{OsO}_{4}$ and embedded in Durcupan ACM.

Sections were cut with a Tesla BS 490 ultramicrotome. Semithin sections $(250-300 \mathrm{~nm})$ were stained with $1 \%$ methylene blue for $1 \mathrm{~min}$. and $1 \%$ Azur II solution for $1 \mathrm{~min}$., both at $37^{\circ} \mathrm{C}$.

Ultrathin sections were counterstained with uranyl acetate and lead citrate according to Reynolds and viewed and photographed with a Tesla BS 613 electron microscope.

Semithin sections were viewed and photographed with an UNIVAR Reichert optical microscope.

\section{Results}

Ultrastructure of the cytoplasm in contact with the matrix of osteoclasts and mineralized ground substance of the cartilage was investigated in longitudinal sections of the metaphyseal margin of the growth cartilage using samples of the tuber coxae from bovine fetuses.

A morphologically variable resorptive margin forms at the resorptive pole of

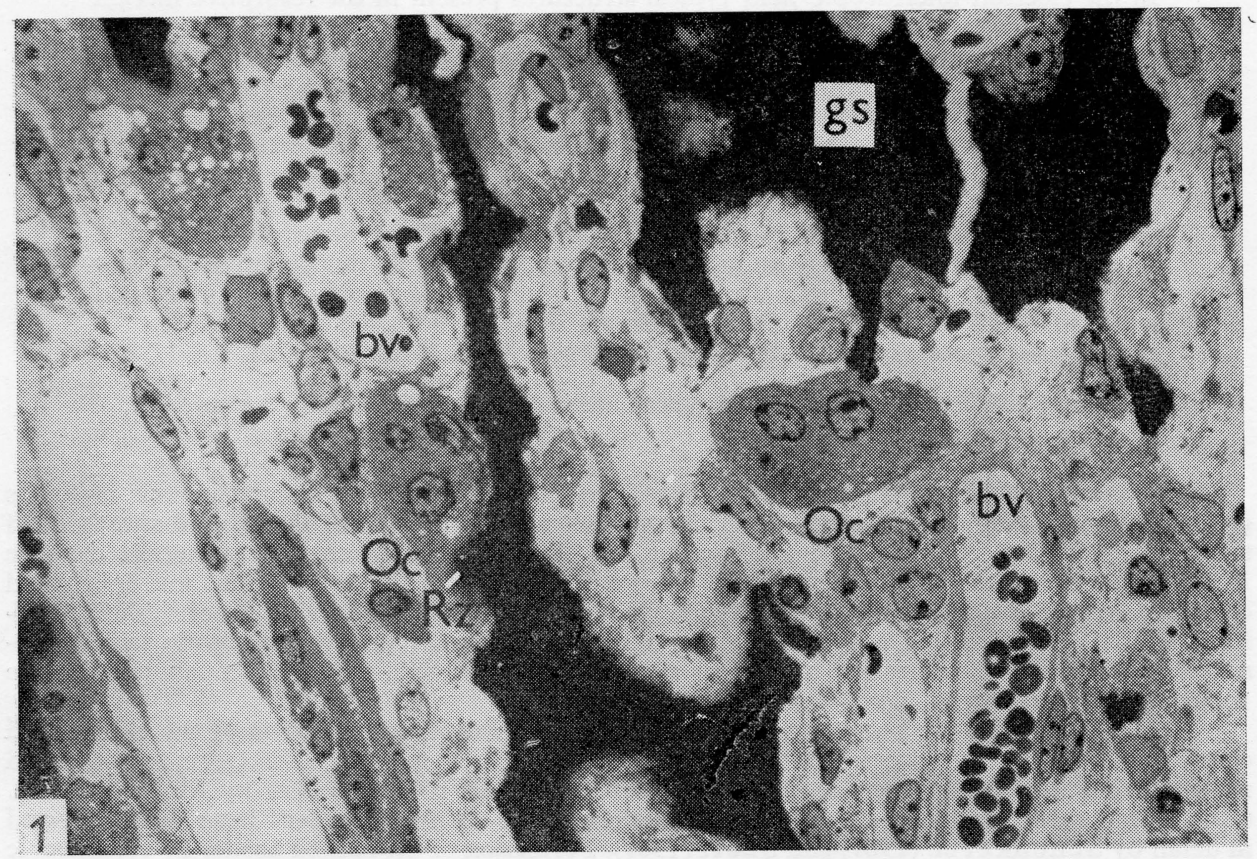

Fig. 1. Osteoid zone of endochondral ossification (semithin section). Oc - osteoclast, bv - blood capillary, gs - mineralized ground substance of the cartilage, $\mathrm{Rz}$ - resorptive margin of the osteoclast. $\times 650$. 
the cell. This zone is concave or an incomplete ring in profile and it encroaches upon the ground matrix. Thus, the shape of the adjacent ground matrix determines to a significant degree the morphology of this structure. With complete envelopment of a larger fragment by an osteoclast, a closed, ring-like resorptive margin forms around the mineralized tissue (see Fig. 5). Significantly, a single cell may form more than one resorptive surfaces as indicated in Fig. 4.

At the site of bone and mineralized cartilage contact, minute and shallow invaginations penetrating into the ground matrix are formed by the plasmalemma of the osteoclast. By these invaginations the actual surface of the plasmalemma

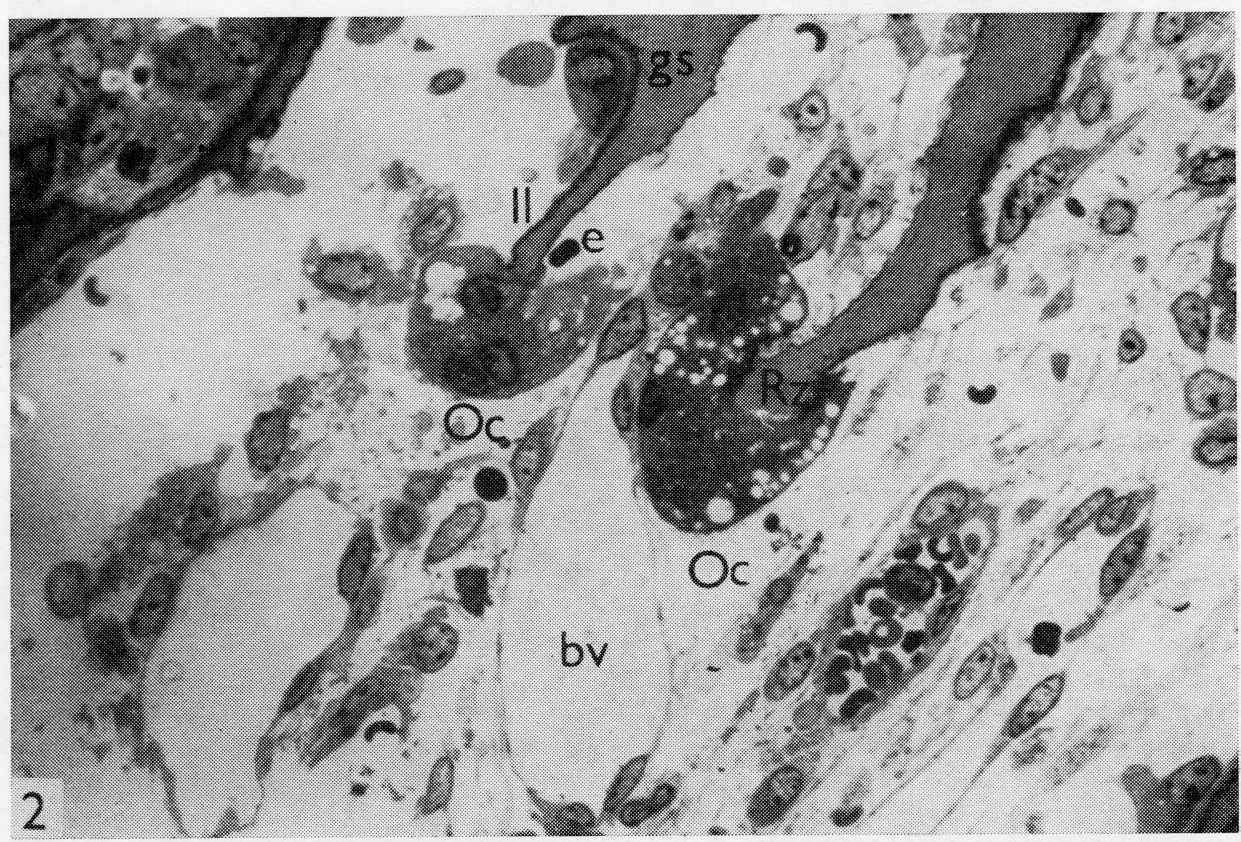

Fig. 2. Osteoclast interposed between the mineralized ground substance of the cartilage and blood capillary (semithin section): Oc - osteoclast, $\mathrm{Rz}$ - its resorptive zone, bv - blood capillary, 11 - lamina limitans, gs - mineralized ground substance of the cartilage. $\times 650$.

exposed to the bone is enlarged considerably. Between these invaginations, phagocytosis of small fragments of the cartilaginous ground substance may be observed. At such contact sites a close relationship exists between the cell and the cartilage while in other parts of the same resorptive margin the space between the cytoplasmic membrane and mineralized ground substance of the cartilage may be found. We designated this space as the intermediate space. It appears without structure or filled with fine granular, slightly osmiophilic material. At sites of seemingly newly formed, narrow spaces the surface of mineralized cartilage present a fine dense lamina as if it were covered by lamina limitans.

The cytoplasm of the resorptive margin contains a dense, strongly osmiophilic material with no apparent organelles. This dense cytoplasm is arranged into 


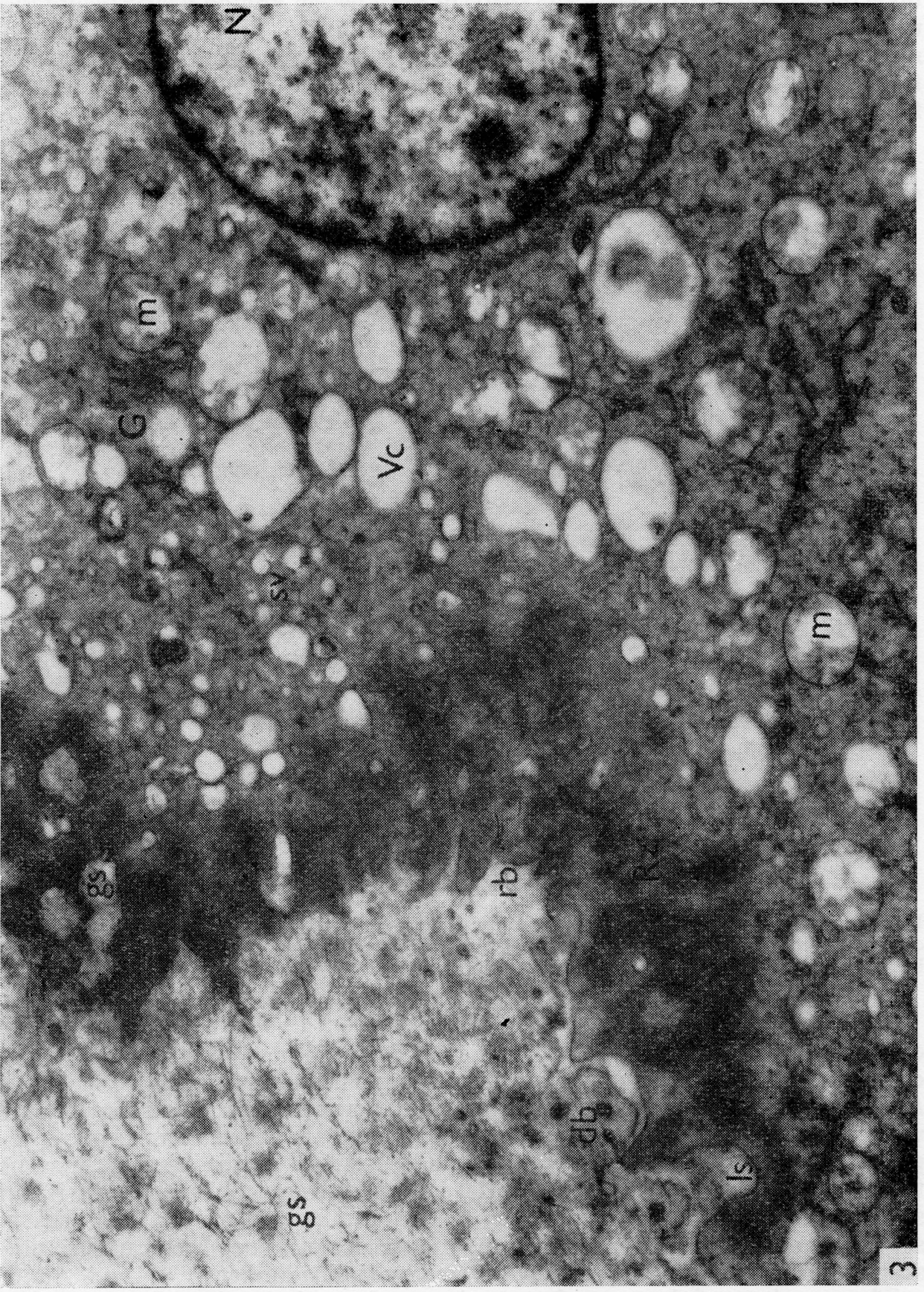




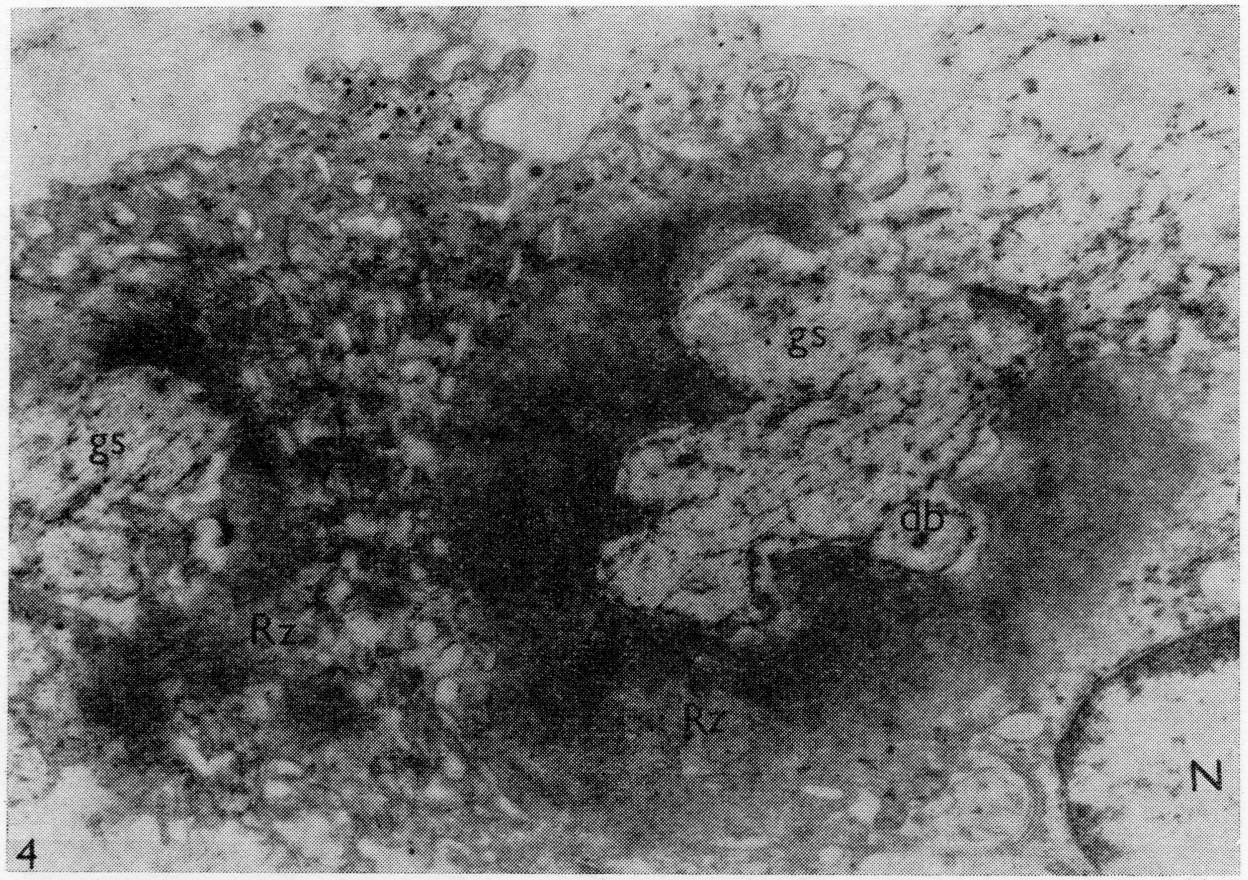

Fig. 4. Phagocytosis of the cartilage with formation of resorptive margins : Rz - modified cytoplasm of the resorptive zone, gs - mineralized ground substance of the cartilage, $\mathrm{db}$ - dense bodies, $\mathrm{N}$ - nucleus. $\times 21400$.

trabeculae running in parallel to one another and oriented radially to the plasmalemma or it also is observed as a dense, net-like structure. In this modified cytoplasm minute vesicles and/or larger ones may be observed. They are limited by a smooth membrane and they contain material of various electron densities.

The cytoplasm adjacent to this margin contains numerous mitochondria arranged in an irregular pattern. Some of them have few inner membrane projections; others contain tubular or vesicular structures in centre, especially near the basal portion of the cell.

The most frequently observed cytoplasmic organelles are the small vesicles coated by smooth membranes. Their number is larger in the resorptive portion of the osteoclast where they populate a large field. However, they are also rather abundant in the basal portion of the cell. Minute vesicles may join to form larger ones occupying a major portion of the cytoplasm (Fig. 6). These organelles are especially conspicuous when fixed with glutaraldehyde (Scott 1967; Schenk et al. 1967). Similar to small vesicles also the vaculoes contain material of various

Fig. 3. Resorptive margin of the osteoclast: $\mathrm{rb}$ - ruffled border, $\mathrm{Rz}$ - modified cytoplasm, Is intermediate space, $\mathrm{db}$ - dense bodies, gs - mineralized ground substance of the cartilage, sv - small vesicles, G - Golgi complex, Vc - vacuole, $\mathrm{m}$ - mitochondria, $\mathrm{N}$ - nucleus. 


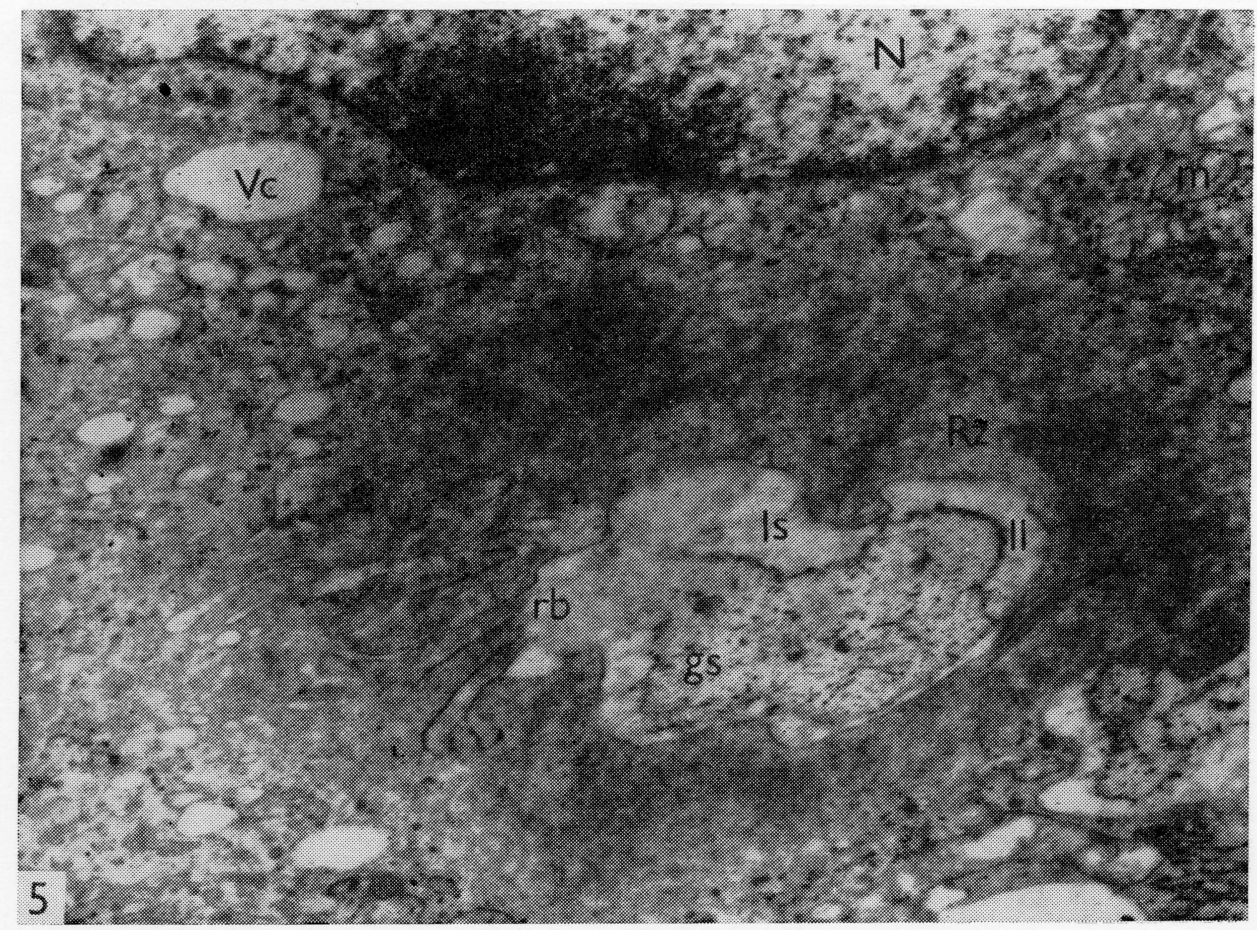

Fig. 5. Intracellularly formed circular resorptive margin: $\mathrm{N}$ - nucleus, $\mathrm{Vc}-$ vacuole, $\mathrm{m}-\mathrm{mito}-$ chondria, $\mathrm{Rz}$ - modified cytoplasm of the resorptive zone, $\mathrm{rb}$ - ruffled border, Is - intermediate space, 11 - lamina limitans, gs - mineralized ground substance of the cartilage. $\times 21400$.

electron density. They contain primarily a fine granular, slightly osmiophilic material, but in some larger vacuoles, on the contrary, large, quite dense granules are visible. Some vacuoles demonstrate no structure resolvable by these procedures.

The basal portion of the cell is in close contact with endothelial cells of blood capillaries. Here it appears that intracellularly transported substances are being extruded into the extracellular space, i.e. between the osteoclast and the endothelial cell. Between the plasmalemma of the basal portion of the osteoclast and the basal margin of the endothelial cell numerous small vesicles appear.

\section{Discussion}

Destruction of the mineralized tissue by multinucleated cells, osteoclasts, has been described as osteoclastic resorption. Mostly the huge multinucleated cell is called osteoclast with no consideration of the type of mineralized tissue destroyed by this cell. Only Schenk et al. (1967) and Savostin and Asling (1975) described the huge multinucleated cell as chondroclast.

In our opinion, from the functional point of view there is only one cell type 
with the main function being degradation of the mineralized matrix. Therefore we call them osteoclasts for the sake of simplicity. However, osteoclasts/chondroclasts destroying the cartilage are described as being simple more than osteoclasts degrading the bone tissue (Lucht 1972).

These multinucleated cells appeared at sites of seemingly intensive resorption. Their appearance was limited to the osteoid zone, only rarely they were detected in close contact with the cartilage in the erosion line. This situation was mostly found in terminal parts of the trabeculae. By osteoclastic activity an intensive resorption of the cartilage ground substance occurred resulting in gradual shortening of the trabeculae of the osteoid zone in the direction of the erosion line.

The osteoclast is characteristically found between the mineralized matrix and the blood capillary. With the resorptive surface or pole of the cell adjacent to the cartilage and the basal portion in contact with the endothelium, such position of the cell would facilitate the transport of substances by the cell more directly to the blood capillary.

At the site of cell contact with the mineralized matrix the osteoclast forms a morphologically specialized structure designated the ruffled border. Formation of the resorptive margin is believed to be a prerequisite for resorption according to several authors (Knese 1972; Kallio et al. 1979; Holtrop et al. 1979).

To the contrary, our results would suggest that the cytoplasmic contact of an osteoclast with mineralized matrix of the cartilage does not form this characteristic ruffled border, but a resorptive surface constisting of small and rather inconspicuous invaginations and densely stained cytoplasm. Despite this fact (the cytoplasmic invaginations penetrate into the ground substance) destruction of the ground matrix does occur. Between the invaginations fragments of cartilage are visible. These it would seem are phagocytized, destroyed, and transported to the basal portion of the cell as has been described for other species.

The osteoclast which brings about resorption of the mineralized cartilage is not morphologically identical with that cell of similar function but found resorbing bone tissue. In the latter cell the cellular contact is made through a ruffled border characterized by numerous long cytoplasmic projections. The functional activity of the cell related to active resorption determines the morphology of this ruffled border. At sites with less functional involvement of the osteoclast another type of cytoplasmic contact is formed with short, broad projections. In this case, the dense cytoplasmic modification is apposed to the cytoplasmic membrane (Malkani et al. 1973). This type of ruffled border is called the "clear zone" by Cameron (1963), Malkani et al. (1973) and Holtrop et al. (1979), "ectoplasmic layer" by Scott (1967), and "transitional zone" by Lucht (1972).

In our material, the cytoplasmic contact of the multinucleated cells with the mineralized matrix in the osteoid zone was formed exclusively by this type of ruffled border designated by us as a resorptive margin. It seems that the type of mineralized tissue and the degree of its mineralization is a decisive factor conditioning the formation of a specialized cellular structure, i.e. the ruffled border characteristic of the osteoclast or a resorptive margin characterized by short evaginations and dense cytoplasm.

The ground matrix of cartilage is less mineralized than the bone tissue. Therefore, its osteoclastic resorption might not be occurring in conjunction with a functionally more demanding resorptive activity.

In spite of a different arrangement of the ruffled border we still regard this structure as a functional and rather exclusive one providing the cell-to-matrix. 


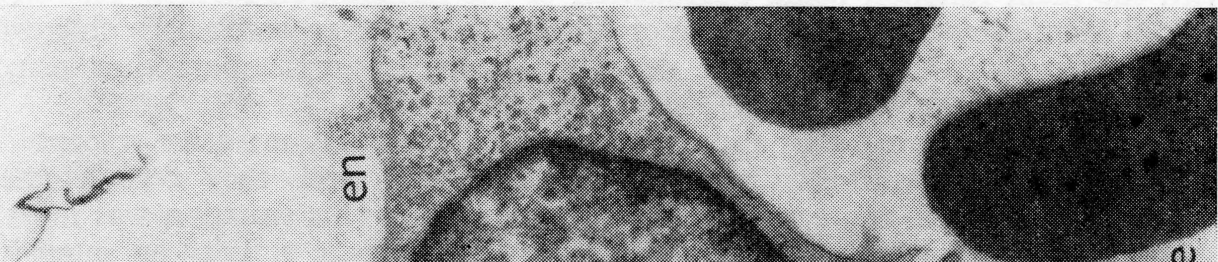

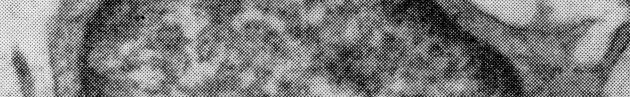

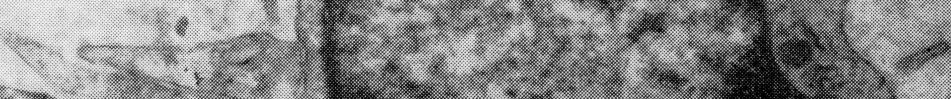

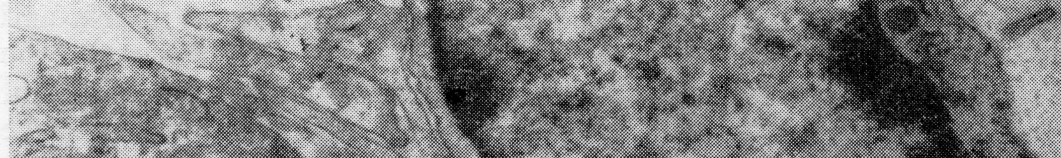

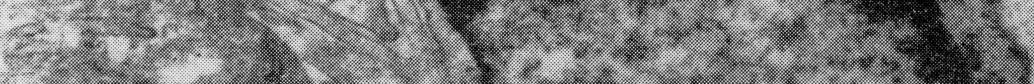

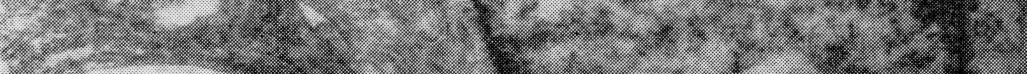

:

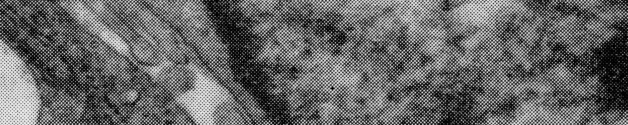

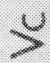
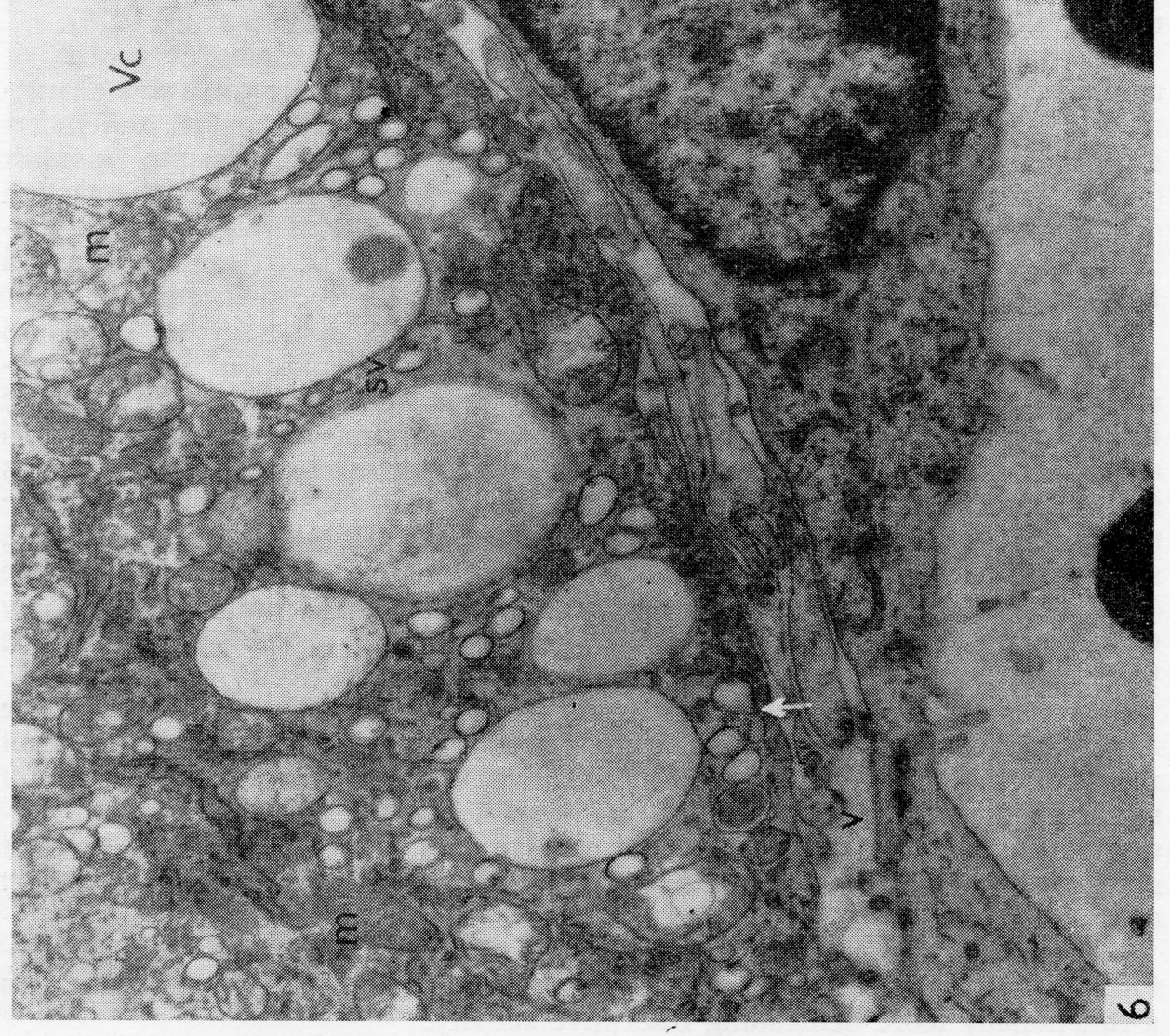
contact of the osteoclast in the osteoid zone. In addition to the generally described concave shape of the structure, we observed a variety of shapes including open or closed ring-like or circular zones with intracellular positions.

A single osteoclast may form more than one plasmalemmal contact with the mineralized matrix as demonstrated by Lucht (1972) and by our data.

The component of organelles of a bovine osteoclast does not differ from that of other species. So far we confirm the conclusions by Lucht (1972) who found no substantial species differences in the structure of osteoclasts. Again, however, it seems that the structure of the multinucleated cell resorbing the cartilage is simpler than that of a bone-destroying osteoclast.

This pertains especially to the specific dense granules in the cytoplasm, described by Scott (1967) as dense granules, and by Lucht (1972) as cytoplasmic bodies. In our study they were observed as vesicular structures limited by a non-coated membrane with contents of various electron densities.

In our view, the cytoplasmic vesicles may originate in two ways. They form as membrane derivatives of the modified ruffled border through endocytosis of matrix, transporting the resorbed material. In the course of this transport they destroy the material, forming larger vesicles. The largest vesicles are found chiefly in the basal portion of the cell. Lucht (1972) demonstrated that vacuoles originating from the cell membrane yield a positive acid phosphatase reaction. In our opinion, the intravacuolar material is degraded in the course of transport. Vesicles with dense contents we regard as lysosomal structures present not only in close vicinity of the Golgi complex but also in the peripheral cytoplasm. Descriptive nomenclature of these structures varies considerably: "vesicles with dense contents" (Schenk et al. 1967), "specific granules" (Scott 1967), "dense bodies" (Lucht 1972), "lysosomes" (Lucht 1972) are equally numerous in the osteoclast of the osteoid zone as in other more typical osteoclasts engaged in resorption of bone tissue. The finding of numerous cytoplasmic vesicles is indicative of an intensive resorptive activity of the multinucleated cell although it does not demonstrate a typical ruffled border.

According to the degree of development of the ruffled border Knese (1972) differentiated two basic phases of resorption: the synthetic and the resorptive phase. The synthetic phase is characterized by a moderately developed ruffled border whereas, in the resorptive phase itself, a conspicuous ruffled border is formed along with large numbers of secretory vesicles in the cytoplasm of, in this case, a mononucleated cell.

In our material, the above-mentioned phases could not be distinguished. Furthermore, in the so-called resorptive phase, characterized by large numbers of minute vesicles and vacuoles in the cytoplasm of the osteoclast, no detectable changes of the ruffled border per se were observed.

Mitochondria with few inner membrane projections or few vesicular or tubular profiles were observed in our material. We are inclined, however, to interpret these as artifacts resulting from the processing.

Our material suggests that there is a considerable variability in the arrangement of the resorptive margin. Destruction of the mineralized ground substance of

Fig. 6. Basal portion of an osteoclast with endothelial cell: $\mathrm{m}-$ mitochondria, $\mathrm{sv}-$ small vesicles, Vc - vacuola, en - endothelial cell, e - erythrocyte, newly formed sac indicated by arrow. $\times 26700$. 
the cartilage in the osteoid zone of ossification by the multinucleated cell is a complex process with both the extracellular breakdown of matrix and its phagocytosis involved.

\section{Ultrastruktura a morfologie resorpční zóny bovinního osteoklastu}

Ultrastrukturu resorpční zóny bovinního osteoklastu jsme studovali v osteoidní zóně endochondrální osifikace růstové chrupavky kyčelního hrbolu. Materiál byl získán od 4 fetů skotu $246-271$ dní fetálního věku z metafysárního okraje zmíněné chrupavky a zpracován obvyklým způsobem pro elektronovou mikroskopii.

Multinukleární buňka - osteoklast vytváří $\mathrm{v}$ kontaktu $\mathrm{s}$ mineralizovanou základní hmotou chrupavky specializovanou strukturu - resorpční zónu. Resorpční zóna je analogická struktura s kartáčovým lemem osteoklastu. Typickými strukturami resorpční zóny $\mathrm{v}$ obraze elektronového mikroskopu jsou mělké invaginace cytoplasmatické membrány a modifikovaná buněčná cytoplasma, která je tvořena densním materiálem $s$ výraznou osmiofilií a neobsahuje buněčné organely. $\mathrm{V}$ cytoplasmě resorpční zóny zachycujeme jen drobné vesikuly ohraničené hladkou membránou, jejichž obsahem je jemně granulovaný materiál různé density.

Obecně je uváděno, že resorpční zóna je konkávní, miskovitého tvaru. Pozorovali jsme, že činností osteoklastu se vytvárí morfologicky rozmanitá resorpční zóna ve tvaru neuzavřeného prstence, nebo jako kruhovitá, zcela uzavřená resorpční zóna situovaná intracelulárně. Morfologie resorpční zóny je podmíněna do jisté míry fagocytární činností, kterou jsme $\mathrm{v}$ této funkčně exponované oblasti pozorovali. Z buněčných organel osteoklastu jsme sledovali jen ty, které mají význam pro intracelulární transport resorbovaných substancí do extracelulárního prostoru a do krevní kapiláry.

\section{Ультраструктура и морфология резорбционной зоны остеокласта крупного рогатого скота}

Нами проводились изучения ультраструктуры резорбционной зоны остеокласта крупного рогатого скота в остеоидной зоне энхондральной оссификации ростового хряща бугра тазобедренного сустава. Материал был получен у 4 плодов скота в эмбриональном возрасте 246-271 суток из метафизарных краев упомянутого хряща.

Многоядерные клетки - остеокласт - образуют в соприкосновении с минерализованной основной массой хряща специализированную структуру, играющую важную роль в резорбции минерализованной ткани. Характерными структурами зоны резорбции в изображении электронного микроскопа являются кистеобразное окаймление и модифицированная клеточная цитоплазма, примыкающая к кистеобразному окаймлению. Она состоит из плотного материала с выразительной осмиофилией и не содержит клеточных органелл. В цитоплазме зоны резорбции устанавливаем лишь плотные тельца, появляющиеся также в основной массе хряща, и мелкие, ограниченные гладкой мембраной пузырьки. Они цодержат мелки, гранулированный материал разной плотности.

Общеизвестно, что зона резорбции остеокласта в соприкосновении с минерализованной тканью является вогнутой, в большинстве случаев в форме ча- 
шечки или подковы. Нами было установлено, что совместно с фагоцитарной деятельностью остеокласта образуется вокруг более крупных фагоцитарных фрагментов основной массы минерализованного хряща резорбционная зона в форме неполного кольца или внутриклеточно полностью окружает фагощитарный фрагмент. Форма фагоцитарной частицы обуславливает форму резорбционной зоны. Мелкие, фагоцитарные фрагменты не бывают окружены резорбционной зоной. Из клеточных органелл остеокласта исследовались .ишь те, которые играют роль во внутриклеточном перемегении резорбированных субстанций во внеклеточное пространство и в кровеносную капилляру.

\section{References}

CAMERON, D. A.: The fine structure of bone and calcified cartilage. Clin. Orthop., 26, 1963: $199-228$.

CAMERON, D. A.: The ultrastructure of bone. In: The biochemistry and physiology of bone. Academic Press, New York-London (Bourne, G. H. ed.), vol. 1, 1972, 191-236.

HANCOX, N. M.: The osteoclasts. - In Bourne, H. G.: The biochemistry and physiology of bone. New York, Acad. Press., vol. I., Structure. 2end Ed., 1972, 45-67.

HOLTROP, M. E. - KING, G. J. - COX, K. A. - REIT, B.: Time-Related Changes in the Ultrastructure of Osteoclasts After Injection of Parathyroid Hormone in Young Rats. Calcif. Tiss. Intl. 27, 1979, 129-135.

HORN, V. - DVOŘ́K, M.: New opinions about the differentiation of the bone cells. Acta Fac. Med. Univ. Brunensis, 59, Brno, 1977, 81-88.

HORN, V. - DVOŘÁK, M.: Weitere Erfahrungen über die verschiedenen Formen der Osteoklasie. Z. Orthop. 118, $1980,1-7$.

KALLIO, D. M. - GARANT, P. R. - MINKIN, C.: Ultrastructural effects of calcitonin on osteoclasts in tissue culture. J. Ultrastruct. Res., 39, 1972, 205-216.

KNESE, K. H.: Osteoklasten, Chondroklasten, Mineraloklasten, Kollagenoklasten. Acta anat., 83, 1972, 275-288.

LUCHT, U.: Osteoclasts and their relationship to bone as studied by electron microscopy. Z . Zellforsch., 135, 1972a, 211-288.

LUCHT, U.: Cytoplasmic vacuoles and bodies of the osteoclast: An electron microscope study. Z. Zellforsch., 135, 1972b, 229-244.

LUCHT, U.: Electron Microscope Observations of Centrioles in Osteoclasts. Z. Anat. Entwickl.-Gesch., 140, 1973, 143-152.

MALKANI, K. - LUXEMBOURGER, M. M. - REBEL, A.: Cytoplasmic modifications of the contact zone of osteoclasts and calcified tissue in the diaphyseal growing plate of foetal guinea-pig. Calc. Tiss. Res., 11, 1973, 258-264.

SAVOSTIN-ASLING, I. - ASLING, C. W,: Transmission and scanning electron microscope studies of calcified cartilage resorption. Anat. Rec. 183, 1975, 373-391.

SCHENK, R. K. - SPIRO, D. - WIENER, J.: Cartilage resorption in the tibial epiphyseal plate of growing rats. J. Cell Biol., 34, 1967, 275-291.

SCOTT, B. L. - PEASE, D. D.: Electron microscopy of the epiphyseal apparatus. Anat. Rec., 126, 1956, 465-495.

SCOTT, B. L.: The occurrence of specific cytoplasmic granules in the osteoclasts. J. Ultrastruct. Res., 19, 1967, 417-431.

VAES, G.: On the mechanism of bone resorption: The action of parathyroid hormone on the excretion and synthesis of lysosomal enzymes and on the extracellular release of acid by bone cells. J. Cell Biol., 39í 1968, 676-697.

WALKER, D. G.: Enzymatic and Electron Microscopic Analysis of Isolated Osteoclasts. Calc. Tiss., Res., 9, 1972, 296-309. 